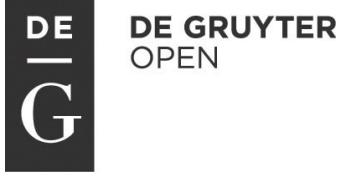

Przedsiębiorczość i Zarządzanie Entrepreneurship and Management University od Social Sciences Publishing House ISSN 1733-2486

Volume XVI, Issue 2, pp. 145-156

DOI 10.1515/eam-2015-0023

Halina Sobocka-Szczapa

University of Social Sciences

\title{
Jobcoaching - a Method of Age Management in an Organisation
}

\begin{abstract}
:
Population aging phenomenon, which takes place globally, forces organisations to change their approach to human resource management. An interest in humanistic approach to management issues, including human resource management, that has been recently popular among HR experts, became the starting point for the analysis presented in this paper. It seems that jobcoaching is closely connected with this notion, which is aimed at understanding and improving the lot of human in the world of organisation, especially when people have the possibility to be active on the labour market for a longer time. Similarly, as in case of the basic assumptions of the humanistic approach to management, jobcoaching puts to the fore the need to understand the personal experience of the members of the organisation. The purpose of this paper is to present the jobcoaching as a method of age management in organisations. The paper verifies a research hypothesis, that in systematically changing conditions of the organisation, the use of jobcoaching can improve the company's operations, as well as it can be a starting point for changing the attitudes of employees and employers to the situation prevailing in the environment.
\end{abstract}

Key words: age management, jobcoaching, age management methods, determinants of age management. 


\section{Introduction}

Population aging phenomenon, which takes place globally, forces organisations to change their approach to human resource management1. Age management, which should change the employers' attitudes towards the type of conducted HR policy, have begun to play an essential role in this process. Among the three theoretical concepts, which explain the change of the personnel function [Brol, zp.lo3.wroc.pl/zim/semestry/sem5/personel/personel_metrialy.doc, s. 141], a situational approach seems to be the most important one. In this approach a change in the business environment results in the need to adapt the organisation to the changing conditions. Change in HR management is therefore a direct reflection of changes taking place outside the enterprise.

An interest in humanistic approach to management issues, including human resource management, that has been recently popular among HR experts, became the starting point for the analysis presented in this paper. It seems that jobcoaching is closely connected with this notion, which is aimed at understanding and improving the lot of human in the world of organisation, especially when people have the possibility to be active on the labour market for a longer time. Similarly, as in case of the basic assumptions of the humanistic approach to management, jobcoaching puts to the fore the need to understand the personal experience of the members of the organisation. Attempts to bring this experience only a truncated, clear and universal message cannot be successful, in the views of researchers, and contribute more to fatigue and discouragement of members of the organization [Kociatkiewicz, Kostera 2013, p. 13]. These attempts also interfere with the perception of diversity, spontaneity and creativity - values which are important for the perception of personal happiness, and thus a greater acceptance of the actions carried out by companies [Kociatkiewicz, Kostera 2010, Van Maanen, Kunda 1989].

The purpose of this paper is to present the jobcoaching as a method of age management in organisations. Jobcoaching enables companies to join knowledge and skills of older workers with a lack of experience and a different kind of competence held by younger workers. The paper verifies a research hypothesis, that in systematically changing conditions of the organisation, the use of jobcoaching can improve the company's operations, as well as it can be

\footnotetext{
${ }^{1} \mathrm{~J}$. Litwiński and U. Sztanderska analysed this issue. They pointed out at least three main factors that define the need to implement age management in organisations: labour shortages, increased propensity of older workers to remain in employment due to the expected higher pension transfers, and the collapse of public finances and pension systems [Litwiński, Sztanderska, 2010, p. 5 and further].
} 
a starting point for changing the attitudes of employees and employers to the situation prevailing in the environment. Verification of this hypothesis will be possible by taking into account reasons affecting the need for age management in organizations that are described in the literature.

\section{Age management - problem outline}

Age management is defined in numerous books and research papers [Griffin, 2009, p. 200, Litwiński, Sztanderska 2010, p. 3, Walker 1997]. In age management definitions, the significance of human resource management in the organisation, which takes into account the possibility of effective absorption of older workers in the companies' operations - the management of processes of workers' aging - is highlighted. It is important that a well-used variety (with regard to human resources in this case) can be a source of competitive advantage, while mishandled HR company policy can become a source of conflict in the organisation. Hence, age management processes can also be analysed from the point of view of diversity management, which guarantees the inclusion of the needs and abilities of employees of different age groups. Generally speaking, it can be stated that the management of age is a way of the management of the company, which takes into account the diversification of the age of the workers through the use of friendly solutions for the older workers employed in companies [Zarządzanie wiekiem 2010, p. 2]. Such solutions are aimed at increasing the productivity of older people, and as a consequence lead to the stabilisation of their professional activity. Due to the fact that these solutions can cover a wide range of instruments and apply to the different phases of employment (recruitment, labour mobility, lifelong learning), as well as they relate to the employee (physical ability, mental) or the environmental dimensions, they were divided into several areas of the age management [Naegele, Walker 2006]. In each of these areas, jobcoaching is perceived as an important method of age management.

So, let us look at what the jobcoaching is.

\section{Jobcoaching - the concept and its elements}

Jobcoaching is one of methods of the unemployed support. However, it may be also used to support workers or people who are at risk of losing their jobs [Rogozińska-Pawełczyk 2007, p. 37], allowing them to maintain employment at current job positions in the same company. In this case, jobcoaching should rely on the cooperation between a worker and a career counsellor, the latter becoming a mediator between worker and the employer. The activities carried out by a jobcoach should be of a highly individualised nature, and rely on 
a detailed diagnosis of the competence of the employee (strengths and weaknesses), as well as the nature of the threats that may be a result of the loss of job. Such recognition may also be associated with the analysis of push and pull factors, resulting in a reduction in labour demand and labour supply of older people2. Push factors would include primarily legal provisions affecting employers' interest in limiting the employment of the older workers (the collective agreement of a protective nature, the need for payment of compensations, dependency of wage levels on seniority), as well as increased importance of ICT as for organisation operations - it means increase, and often radical change in requirements relating to the qualification of the employees. In contrast, the pull factors may mainly include types and size of social benefits and demographic situation [Grzesiak, http://www.zie.pg.gda.pl/c/document_library/ get_file?uuid=89e7dcb4-30a7-4279-9536-93286f3ef0ff\&groupId=10236]. Familiarity of these factors enables a jobcoach to strengthen the position of an older employee in the company and to plan the appropriate course of action in the context of the respective jobcoaching elements: subjectivity, individualism, assessment of the strengths and weaknesses of the employee, defining the goal, and - as a result - the empowerment of an older employee in the workplace (Graph 1).

Subjectivity and individualism of jobcoaching that is conducted in organisations towards people at risk of losing their jobs, should be based on the consideration of the beneficiary's expectations in the advisory process. It should mean outlining a career path by the concerned person, which may strengthen his/her commitment to the objectives of the enterprise.

${ }^{2}$ Such factors have been highlighted by A. Walker and L. Funk [Walker 1985, p. 211 and further pages, Funk, 2004, p. 24]. 


\section{Graph 1. Elements of jobcoaching and the relationships between them}

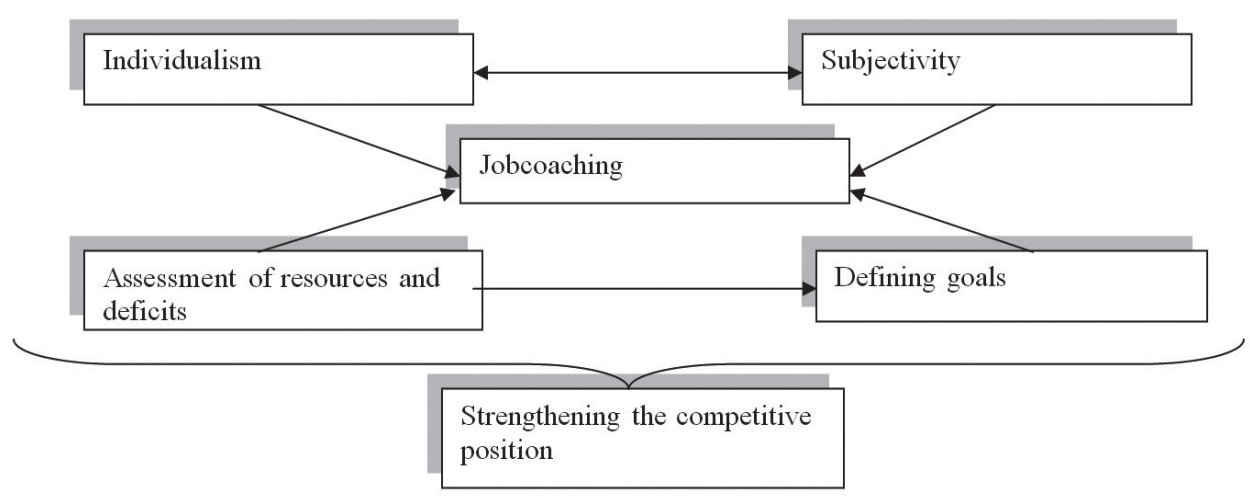

Source: own elaboration.

This shall result in overcoming barriers that reduce the tendency of employers to hire such workers. Defining the career path by the same employee may result in increasing her/his interest in adapting her/his competence to the tasks delivered on the workplace. It is even more important in the case the employee is at risk of dismissal.

Assessment of resources and deficits of person who is supported within jobcoaching should lead to identification of strengths and weaknesses of the employee being at risk of losing job. This process should be extensive, due to the fact that it provides the basis for determining the support actions. Information stemming from this process should help to identify competency gaps, which could be eliminated by conducting training activities. Identified strengths should create a basis for determining career development paths that would be presented to the employer in order to enable utilisation of these strengths in the organisation operations. In many cases the older worker's experience can provide significant capital, which can be used to support new/ young workers in completing their tasks. The exchange of experiences between different generations of employees, provided in this way, can be beneficial to the company as well as it may improve the atmosphere in the organisation.

The result of analysis of the strengths and weaknesses of the employee who is at risk of losing a job should help to define the goal. This should be determined in accordance with the principles of SMART, that is, to be specific (tailored to the specific capabilities), measurable (quantifiable results may be subject to verification), motivation (accepted by the beneficiary, feasible to 
reach), realistic (kind of job available in a particular labour market) and timespecific (actions in accordance with the timing of the implementation of individual development plan)3. Setting a goal should make possible for both the employee and the employer's to assess chances of acquiring the competence/ employee that will be consistent with the tasks performed within the organisation. It is an element of the formulation of an individual development plan, which should be preceded by an assessment professional potential and individual needs of the beneficiary (the current family, professional, material, health situation, and education).

Strengthening the position of a senior employee in the workplace should be a result of the activities carried out by jobcoach. It is very important in this case - as in the whole process of jobcoaching - that the impact should have not only formal, but also mental nature, embedding positive, from the point of view of the organisation, employee's behavior. Career counselor must be convinced, that when an employee will undertake individual actions, it will not result in discouragement and returning to the situation that was before support was offered. Therefore, it is important to inform the management of the organisation about the actions taken within the jobcoaching. The management will be able to support the senior employee in her/his efforts to maintain the current job, if it is compatible with the company strategy. The success of jobcoaching depends primarily on the cooperation between the counsellors and top managers.

Jobcoaching as a method of age management in companies, generally enable better adaptation of older workers to the tasks carried out within the organisation. Improvement of the competitive position of such workers may not only contribute to keeping current employment, but mainly to increase their chances of getting a job also on the external labour market. These workers, having a well-established work habits and work experience are often a key resource of company's human capital - company's operations are often based on their competences. Giving up this capital, caused usually by economic conditions or reorganisation of the workplace, is quite often a difficult decision. Therefore, jobcoaching can be perceived not only as a support for older workers, but also as a way of solving company's problems with the absence of adequate workers. It should be stressed, that the age management with the use of jobcoaching is possible to implement in every company, even in one, where there is no HR department because of too small size of the company. This method allows to

${ }^{3}$ This acronym stands for: Specific, Measurable, Ambitious, Realistic, Time-scaled [Rogozińska-Pawełczyk, 2007, p. 37]. 
apply the rules that does not discriminate older people, but use their potential to the benefit of both parties -the employers and employees.

In the next part of the paper we will analyse determinants that affect the need for age management in organisations, focusing also on the importance of jobcoaching as a method that can be used in this process.

\section{Determinants of age management and the possibility of jobcoaching utili- sation}

Conditions, which cause that age management in companies, become a necessity of modern organisations, are rooted both in the economy, as well as in the activities of the business entities.

From the perspective of the economy, it is particularly important to link age management with lifelong learning. The importance of this relationship stems from both the population aging and low labour market participation of the elderly. Therefore, it is necessary to encourage the elderly to stay in the company, even after reaching retirement age. Difficulties in finding the right employee on the labour market lead to taking actions by the employers that enable the older workers to develop and match their skills with new job openings. This requires searching for a suitable educational offer by the employers, as well as conducting human resources policy, which encourages undertaking of education activities. Jobcoaching method may be of a key importance in this case, enabling the identification of employees' expectations, and specification of education courses that would be in line with the employers' needs. This method can also determine areas, in which there will be possible to take advantage of skills and experience of older workers, to serve as mentors for young employees. On the other hand, due to the low labour market participation of the older people, jobcoaching may lead to an increased interest in extending professional activity, by pointing to the benefits of a longer stay in employment (higher pensions, maintaining contacts with people, being in line with professional issues). A particular advantage of this method is a personal contact with the beneficiary, which affects the greater efficiency of these activities. The phenomenon, stemming from the analysis of statistical data is that, for example, in the Polish economy, there are significant reserves of employment in the group of people over 45 years of age. Their use could significantly offset the projected decline in the number of people in working age [Litwiński, Sztanderska 2010, p. 7]. This also applies to people in the post-working age. However, it is necessary to change the attitudes of employers. Otherwise, in the future many businesses may face problem of labour shortages, resulting not only from the inadequate 
quality of workforce qualifications, but above all, from a very low inflow of young people into the labour market.

The barrier to the wider employment of older people in companies, which indicates the need for implementing age management processes, is also the discrimination of the older workers, resulting from negative stereotypes about this social group. However, an important issue is to adapt the processes within the organisation to changes in the employment policy conducted by the state. Age management should be a response to the regulations, allowing greater use of older labour resources management in economic processes. So, associated activities undertaken by companies that aim at retaining such employees are necessary. Changing legal regulations may contribute to the formation of conditions favouring such measures. However, it should be stressed again, that before this, employers must change their negative perception of older people as potential employees. Jobcoaching, as the method used in the age management, may contribute to changing this perception, enabling detailed diagnosis of older workers' competences, and pointing out areas of the economy, where the use of such workers can bring the best results.

From the perspective of the company, the need to implement age management and to combine it with lifelong learning may, however, be related to the following reasons [Litwiński, Sztanderska, 2010, p. 8 and further]:

- firstly - a company can achieve tangible benefits resulting from the age diversity of workers; this diversity enable to better respond to rapidly changing market conditions, and, in particular, allows for better adjustment of production to the diverse needs of customers; jobcoaching may be helpful in this respect as it allows for the verification of recruitment in terms of diversity in age and skills dimensions,

- secondly - for the organisation it is important to maintain the appropriate level of competence; according to research studies, professional and social skills of older workers represent a unique type of human capital; older workers' accuracy, reliability and the ability to communicate with clients and colleagues is, in many cases, the added value which is not possessed by younger or new employees [Giza-Poleszczuk, Góra, Litwiński, Sztanderska 2008]; similarly important is the ability to solve difficult problems; such competences cannot be replaced, because this process is costly, besides, lack of such competences may result in profit losses; at the same time - what should be emphasized - if older workers perform tasks in line with their qualifications, their performance is comparable to that of younger workers [Rolland, 2004]; additional advantage is the possibility of intergenerational exchange 
of knowledge and skills, which results in continuity of the stock of knowledge; jobcoaching, by implementation of its elements, can have an influence on validation of advantages of older workers, and thus may be a method supporting counteracting the mental barriers among employers and employees, hindering the labour market participation of the latter group,

- thirdly - diverse, but at the same time balanced age structure of employees, may reduce the labour costs; high costs of employment of older workers in the organisation can be compensated by introducing measures promoting health, workplace ergonomics, improving skills, motivating older workers and linking their wages to their performance, which should result in a reduction of employment costs of such persons, primarily because of labour productivity growth; these actions may be more effective compared to replacement of older worker by a younger one, if the costs of adapting new employee to the workplace is taken into account; in this case jobcoaching may also be seen as a method of age management that enables verification of the suitability of a senior employee in comparison with hiring new employee.

The above mentioned advantages of age management, including the use of jobcoaching, becomes even more important in the case of changes on the labour market. Limited access to the young human resources, as well as the introduction of new legislation that promotes the older people in the role of employees, creates additional preferences to wider employability of this group.

\section{Conclusions}

The use of age management by organisations, as a way to maintain older workers labour market participation, entails a clear advantages. However, age management should not be considered as an approach directed solely to the older people, because such action would expose managers to the allegation of discrimination other employees. It should be rather understood as a policy of equal opportunities for all employees. However, due to external factors, age management is usually seen in terms of the need to encourage people from the upper bound of the working age population, as well as post-working age population, to be economically active. The reason for this is a significantly low labour market participation observed in these groups, which may cause the difficulty in achieving appropriate level of efficiency by organisations, related to problems with filling vacancies by the young employees [Kryńska 2013, p. 9, Sobocka-Szczapa 2013, p. 63]. 
The method of jobcoaching described in the paper, which can be used in the age management in companies, seems to be a method, that may eliminate barriers associated with low labour market participation of older people. On the one hand, jobcoaching simplifies the assessment of skills and development of career paths for senior employee. Thus, it creates the conditions for undertaking or maintaining her/his economic activity. On the other hand - it helps to overcome stereotypes related to older workers. At the same time, jobcoaching brings significant benefits for the company, which arise from the age diversity of the workforce and allow for discounting all the advantages of the older workers.

However, if this described method is to be an effective tool of age management, there is a need to avoid mistakes distorting the meaning of the practice and precluding the achievement of defined objectives. The most common mistakes would include [Rogozińska-Pawełczyk, 2007, p. 42 and further]:

- putting emphasis on the process, not on the target, which means that the effectiveness of jobcoaching should be verified by achieving the objective, not by providing various supporting activities,

- deviations from individual development plans, resulting in claims among the beneficiaries. Fulfilling these claims does not help to achieve the objective (e.g. participation in training not included in the IDP),

- simplifications introduced by the individual career counsellor that stems from excessive bureaucracy burden and filling documents by the beneficiary; it results in poor quality documentation, which has an impact on the whole process; similar problem arises when jobcoach narrows down her/his actions to telephone conversations,

- not taking into account the needs of employers, which leads to a lack of their interest in undertaking jobcoaching in the organisation; use of this method should focus on meeting the needs of both parties - the employees and the employers,

- imbalance between time of work and devoted to achieving goals of the personal development plan; this problem applies mainly to working population; planning activities which are impossible to implement due to lack of time can have a negative impact on the person who is counselled and on the career counsellor,

- lack of adjustment of the workplace to the needs of jobcoaching; lack of access to various means of telecommunications reduces quality and effectiveness of undertaken actions. 
Regardless of the above mentioned threats to the effective application of the jobcoaching, it seems that this method may be effective4, since it gives the opportunity to perceive human being from the individualistic as well as holistic point of view. This perception affects the implementation that needs respect, recognition, which - especially in relation to the older worker - are essential for the effect of his work. That is particularly important that the work at the moment is characterized by variability (due to saturation of knowledge and instrumentation), which is not without significance for the human psyche. Therefore, the aim of management processes, including human resource management, to take into account the expectations of the employee, with appropriate management methods, seems to be the most effective in terms of business procedure.

\section{References}

Brol M.W., Zarządzanie personelem, zp.lo3.wroc.pl/zim/semestry/sem5/personel/ personel_metrialy.doc-access 10.11.2014.

Dobrowolska M.A. (2013), Jobcoaching - przyktad dobrych praktyk, „Forum Oświatowe", 2/49.

Funk L. (2004), Employment Opportunities for Older Workers: A Comparison of Selected OECD Countries, DICE Research Report.

Giza-Poleszczuk A., Góra M., Litwiński J., Sztanderska U. (2008), Dezaktywizacja osób w wieku okotoemerytalnym. Raport z badań, Departament Analiz Ekonomicznych i Prognoz, Ministerstwo Pracy i Polityki Społecznej, Warszawa.

Griffin R. (2009), Podstawy zarzadzania organizacjami, PWN, Warszawa.

Grzesiak M. (2014), Motywy wdrażania strategii zarzadzania wiekiem w przedsiębiorstwach, http://www.zie.pg.gda.pl/c/document_library/get_file?uuid=89e7dcb4-30a7-4279-9536-93286f3ef0ff\&groupId=10236 - access 10.11.2014.

Kociatkiewicz J., Kostera M. (2010), Experiencing the Shadow. Organizational exclusion and denial within Experience Economy, "Organization", 17 (2).

Kociatkiewicz J., Kostera M. (2013), Zarządzanie humanistyczne. Zarys programu, „Problemy Zarządzania”, vol. 11, no 4(44).

Kryńska E. (2013), Wprowadzenie [in:] E. Kryńska (ed.), Elastyczne formy zatrudnienia i organizacji pracy a aktywność zawodowa osób starszych, IPiSS, Warszawa.

\footnotetext{
${ }^{4}$ Research, to allow verification of the hypothesis of economic reality, is still currently rare. Studying literature encountered an example of good practice in the Netherlands [Dobrowolska 2013].
} 
Litwiński J., Sztanderska U. (2010), Zarządzanie wiekiem w przedsiębiorstwie, PARP, Warszawa.

Naegele G., Walker A. (2006), A guide to good practice in age management, European Foundation for the Improvement of Living and Working Conditions, Dublin.

Rogozińska-Pawełczyk A. (2007), Jobcoaching czyli indywidualne doradztwo zawodowe dla osób w wieku 45+ [in:] B. Urbaniak (ed.), Pracownicy 45+ w naszej firmie, UNDP, Łódź.

Rolland L. (2004), The Age Chasm: Successfully Managing Age in Your Organisation, Drake White Paper, Vol. 2, No. 5, Australia.

Sobocka-Szczapa H., Poliwczak I. (2013), Sytuacja osób w wieku 45+ na rynku pracy $w$ Polsce i wybranych krajach Unii Europejskiej [in:] E. Kryńska (ed.), Elastyczne formy zatrudnienia i organizacji pracy a aktywność zawodowa osób starszych, IPiSS, Warszawa.

Van Maanen J., Kunda G. (1989), Real feelings. Emotional expression and organizational culture [in:] L.L. Cummings, B. M. Staw (ed.), Research in organizational behaviour, vol. 11, JAI Press, Greenwich.

Walker A. (1997), Combating Age Barriers in Employment. European Research Report, European Foundation for the Improvement of Living and Working Conditions, Dublin.

Walker A. (1985), Early Retirement: Release or Refuge from the Labour Market?, "The Quarterly Journal of Social Affairs", 1(3).

Zarządzanie wiekiem - szansa dla przedsiębiorców. Mini przewodnik zarządzania wiekiem (2010), Akademia Rozwoju Filantropii, Warszawa. 